\title{
Sensory Evaluation of Winter Cereal Silage
}

\author{
Carlos Eugênio Fortes Teixeira ${ }^{1}$ and Renato Serena Fontaneli ${ }^{2}$ \\ 1. Tecnico em mecânica, Engenharia Mecânica-IFSul-Campus Passo Fundo, Passo Fundo, Brazil \\ 2. Agronomia/ppgAgro UPF, Universidade de Passo Fundo, Passo Fundo, Brazil
}

\begin{abstract}
Silage is aimed at conservation of green fodder, with minimal losses and that this kind of food, does not occur formation of toxic compounds for animals. Practical aspects become important when control "in loco", reflects management practiced in the property. There are different sensory evaluation techniques. The objective of this work was to study the applicability of the German system, now used in sensory evaluation of winter cereals (wheat silage and haylage oats). For quantitative analysis of silage (pH) that was used potentiometer. In determining the qualitative analysis was used German method adapted. Relating them to sensory characteristics such as smell, texture and color of the fodder saved by assigning a score to each sensory: a "key" predetermined quality identification. For multiple comparisons for film types tested in oat silages BRS Centauro, the results show that the qualitative sensory attributes evaluated by rating corresponded to the quantitative attributes $(\mathrm{pH})$ evaluated, with no difference. For multiple comparisons in the silages, for all test loads in both wheat genotypes results showed no difference between the qualitative evaluation (sensory) and quantitative.
\end{abstract}

Key words: Ensiling, pre drying, quality.

\section{Introduction}

The objective of the ensiling is the conservation of green fodder, with the minimum of losses and that in this type of food, there is no formation of toxic components for the animals [1]. In order for the silage to have a satisfactory final quality, it is necessary for the property to know the most important factors that the silage presents for its use.

There are good correlations when using "in vitro" and "in vivo" analysis techniques, but there is no data accuracy due to laboratory variations, sampling, animal handling and diet.

Some authors describe the use, relevance and methodologies used in the quality studies of preserved forages (silages). Existing on exist the constant search for development of methodologies and improvement of existing ones, these authors report that Brazilian researchers, demand for the use of new methodologies, in the evaluation of silages [2].

Corresponding author: Daniel Jungues, doctor, research field: animal science.
The term silage quality is often related to the chemical-bromatological characteristics of the forage. There can be several losses from the fermentation process. Among the visible highlights is the presence of mold, darkening of the ensiled product, and effluent produced. Evaluations based on the human senses, such as vision, smell and touch, are important, as are chemical and bromatological evaluations. Also serving as an indication of the nutritional quality, sanitary aspects and presence of agents are foreign to silage [3].

There are different sensory evaluation techniques. Researchers from EMBRAPA (Brazil) developed a key, based on punctuation punctuated physical-chemical characteristics such as $\mathrm{pH}$, ammoniacal nitrogen contents and organic acid contents. So that later, it conceptualized the quality of the fermentative process (very good, good, steady, etc.) [4]. In the same way, concepts of good to worse, related to fermentative parameters ( $\mathrm{pH}, \mathrm{CP}$ (Crude protein), dry matter digestibility) were developed in the UK (United Kingdom) for hay and silage quality, used in beef and sheep feed [5]. 
The system Grobfutterbewertung: Teil A-DLG-Schlüsselzur Bewertung von Grünfutter, Silage und Heumit Hilfe der Sinnenprüfung is a German system of analysis, very complex, composed of identification methodologies. When the sensorial attributes, such as color, texture, smell, of the fermented product are analyzed, a concept for preserved fodder is later established [3].

The objective of this work was to study the applicability of the German system in a new form for sensorial evaluation of winter cereals (wheat silage and wilted oats) compared to quantitative data.

\section{Material and Methods}

Two wheats were used for the silage test: BRS Pastoreio and BRS Umbu wheat; In the same way for haylage the black oat BRS Centauro was used. The plastic films used for the haylage, with the following characteristics: Low density polyethylene-LDPE 130 $\mu \mathrm{m}$ thick, polyester canvas $300 \mu \mathrm{m}$ thick and polyester/vinyl canvas $370 \mu \mathrm{m}$ thick. PVC silos of approximately $300 \mathrm{~mm}$ in length and $100 \mathrm{~mm}$ in diameter with lids. A hydraulic press of capacity for 10 tons marks NEO PRH 810. KASVI potentiometer was used for the quantitative analysis of the silage $(\mathrm{pH})$. In determining the qualitative analysis, the adapted German method was used. The objective of this evaluation is to estimate the quality of the silages. Relating sensory characteristics, such as odor, texture and color of the preserved fodder, assigns a note to each sensory item, according to a predetermined "key" of quality identification. At the end, depending on the sum of the grades, the final grade is given and a concept for the silage is given. The analysis of variance was performed by free software Action 2.9.

The compaction test in wheats was determined and conducted in four loads $(10,20,30$ and $42 \mathrm{kN}$ (kilo NEWTON)).

\section{Results and Discussion}

In the qualitative and sensory analysis of the haylage (butyric acid, acetic acid, heating, yeast, fungus, brown staining, yellowish coloration, other observations, texture, $\mathrm{pH}$ ) that are shown in Table 1. Where table $\mathrm{pH}$ was determined by the use of the potentiometer and later converted into note. These results can be translated, for some reasons: there was retention of moisture between the plastic and the bale, which was evidently proven in the opening of the same, caused by fermentations of different natures. The thickness and film type have set up different barrier properties. Using this methodology previously mentioned, it was arrived at that: at least two bales showed scent of butyric acid; Most of them had a slight acetic acid odor (higher notes for this component) (Table 1). This, according to some authors, is explained due to the anaerobic bacteria in phase 2 of the fermentation process; Transforming plant sugars into organic acids, alcohols, carbon dioxide and nitrogen compounds. The produced organic acids begin to reduce the $\mathrm{pH}$, from about 6 (six) to 5 (five). If the $\mathrm{pH}$ of the silage begins to fall slowly and the moisture concentration is high, bacteria

Table 1 Quantitative and qualitative data of the analyzes for haylage of black oats BRS Centauro.

\begin{tabular}{|c|c|c|c|c|c|c|c|c|c|c|c|c|c|c|c|c|}
\hline 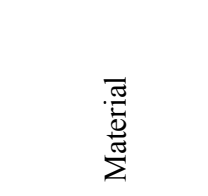 & 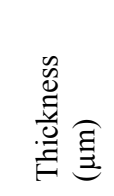 & 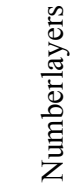 & 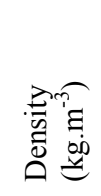 & 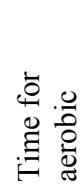 & & $\stackrel{I I}{2}$ & 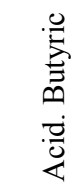 & 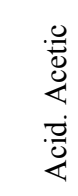 &  & 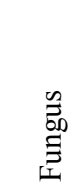 & $\frac{5}{0}$ & $\frac{\bar{c}}{\frac{0}{0}} \frac{0}{\overline{0}} \frac{0}{0}$ & 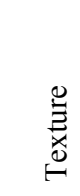 & $\begin{array}{l}\frac{0}{2} \\
\stackrel{0}{0} \\
\square \\
0\end{array}$ & $\begin{array}{l}\stackrel{0}{0} \\
\text { Z }\end{array}$ & $\begin{array}{l}\overrightarrow{0} \\
0 \\
0 \\
0\end{array}$ \\
\hline Polyethylene & 130 & 2 & 392.6 & 62 & 4.5 & & 0 & 0.6 & 0 & 2.6 & 0.3 & 0.3 & 0.3 & 1 & 3 & $\mathrm{~S}$ \\
\hline Polyester & 300 & 2 & 437.1 & 90 & 5 & & 1 & 1.5 & 0 & 0 & 0 & 0 & 0.5 & 1.7 & 3 & $\mathrm{~S}$ \\
\hline Polyester/vinyl & 370 & 2 & 501.2 & 124 & $4 .^{\circ}$ & & 0 & 1 & 0 & 1,5 & 0 & 0,5 & 0.7 & 1 & 2 & G \\
\hline
\end{tabular}

$\mathrm{S}=$ steady; $\mathrm{G}=$ good. 
Table 2 Multiple comparisons for sensorial analysis $+\mathbf{p H}$ value in the haylages of black oats BRS Centauro (Kruskal-Wallis test).

\begin{tabular}{llll}
\hline Multiple comparisons & & & \\
\hline Comparative factors & Difference observed & Critical difference & Difference \\
\hline LDPE-polyester & 4.20 & 6.46 & No \\
LDPE-polyester/vinyl & 0.41 & 6.46 & No \\
Polyester-polyester/vinyl & 4.62 & 7.08 & No \\
\hline
\end{tabular}

of clostridial origin can grow. These bacteria degrade sugars and convert lactic acid to butyric acid, releasing strong odors [6]. None presented heating or yeast; Fungi were present in at least six bales, detected at the closing extremities; There was change in the brown and yellowish coloration in only two; Two bales were condemned or poorly evaluated; Color brown represents heating during storage or aerobic exposure, presenting low digestibility [7]. The texture has changed in the coverage of polyester/vinyl films: it is believed by the presence of moisture and fermentation (in this case, acetic acid) (Table 1). The slight smell of vinegar represents the situations in which there were worse fermentations, dominated by acetic bacteria, with probable decrease of the intake by the animals $[3,7]$. Researchers in sensory analysis established some sensorial fermentation quality relationships, with operational aspects of silage and desensiling: silages considered "good", do not have strong smell and are easy to be unstrained due to good lactic fermentation. "Poor" silages, called "butyric", have an "offensive" smell; The so-called "Ammoniacal" silages were characterized by high ammonia, caused by protein degradation, slow $\mathrm{pH}$ drop or clostridium fermentation, originating from poorly compacted silages, tending to have high ammonia. The "poor" silages of acetic origin presented a smell of vinegar, and also characteristics such as: Extremely humid silage, slow fermentation (due to the high buffer capacity), badly sealed, and silage filling performed in most cases, slowly. The "poor" classified as ethanolic presented, "sweet" smell; Indicative of yeast fermentation, high losses when exposed to air. Finally, those classified as "moldy" silages were the result of slow filling, poorly compacted or sealed silage, or poor wrapping in the use of haylage plastic film [8]. Finishing the qualitative analysis, the Kruskal-Wallis test was applied (Table 2). The result showed that there is no significant difference between the notes and their respective concepts (bad, steady, good and very good).

In the sensory analysis, for wheats under compaction, for three attributes verified: color, texture and odor, there was only attribution of note 1 (slightly alcoholic odor or acid, slightly attacked texture (sticky to the touch), very little change in color) for the loads Low $(10 \mathrm{kN})$. The classification of the silages of the two wheats was very good and good, with no regular classification and worse. It was shown that the qualitative attributes (sensory analysis) of the silage, accompanied the quantitative attribute analyzed in this experiment $(\mathrm{pH})$. The effects graphs (Fig. 1 and Fig. 2) represent the application of the Kruskal-Wallis test on the final notes obtained from the sensorial evaluation, under the silages of the wheat genotypes. 


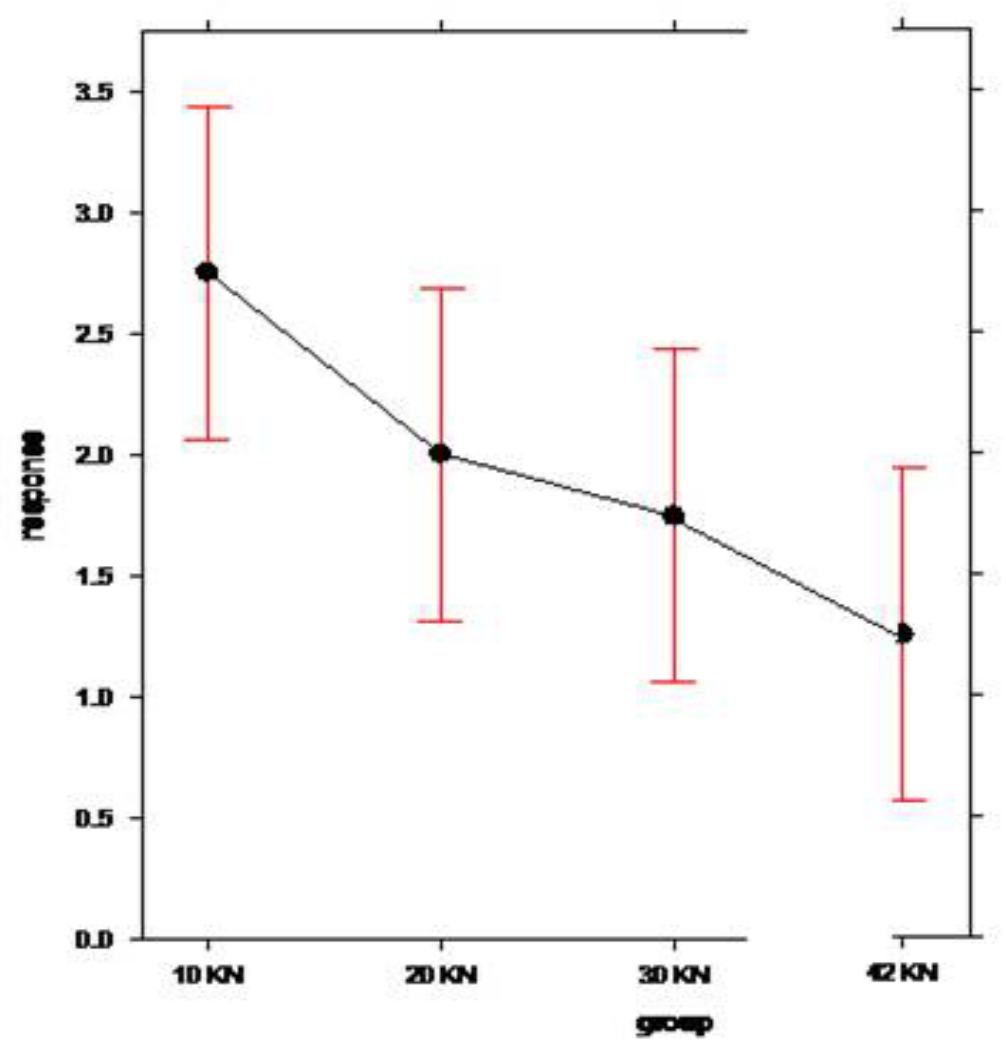

Fig. 1 Relationship between the note of the sensorial evaluation (axis Y) and effect of the load (kN) (axis X) on the fermentation of wheat silage BRS Umbu.

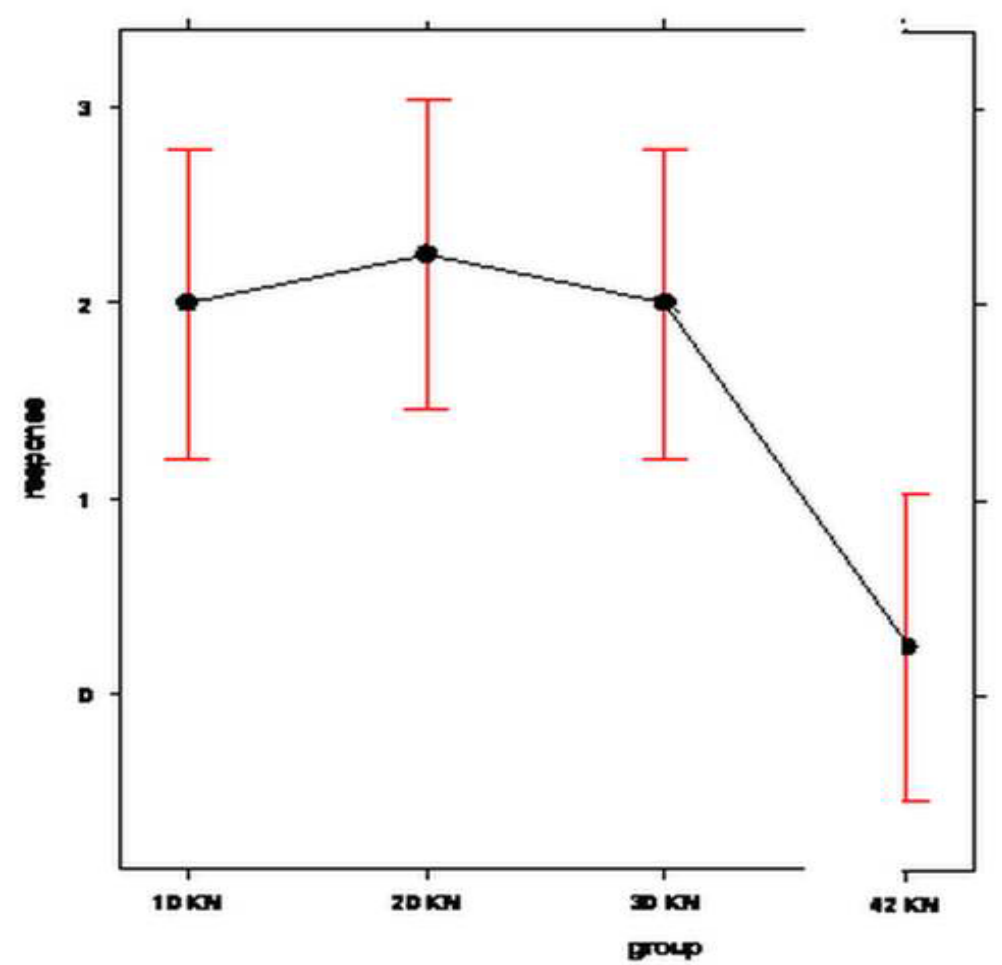

Fig. 2 Relationship between the note of the sensorial evaluation (axis Y) and effect of the load (kN) (axis X) on the fermentation of wheat silage BRS Pastoreio. 


\section{Conclusions}

The results demonstrate that the qualitative sensorial attributes evaluated under note, corresponded to the quantitative attributes $(\mathrm{pH})$ evaluated. For the multiple comparisons made in the silages, for all the test loads, applicable to the wheat and other winter cereals tested, the results showed that there is no difference between the qualitative (sensorial) and quantitative evaluation. The results also demonstrated the applicability of a new methodology for trials of winter cereal silage under low latitude conditions.

\section{References}

[1] Freixal, R., and Alpendre, P. 2013. Conservação de Forragens: Ensilagem. Escola de Ciências e Tecnologia Departamento de Fitotecnia. Universidade de Évora, PT. 2013b. 51p. Disponível: https://dspace.uevora.pt/rdpc/bitstream/10174/9440/1/Co nserva $\%$ C3\%A7\%C3\%A3o\%20de\%20Forragens $\% 20$ Ens ilagem\%20(2).pdf Acesso: dez 2015.

[2] Jobim, C. C., Nussio, L. G., Reis, R. A., and Schmidt, P. 2007. Avanços Metodológicos na Avaliação da Qualidade da Forragem Conservada. R. Bras. Zootec. v.36, Suplemento Especial, p.101-19.

[3] Junges, D. 2011. Avaliação Sensorial da Qualidade de Forragem Conservada. Centro de Pesquisa em
Forragicultura - UFPR. Universidade Federal do Paraná. 2011.13p. Disponível em: http://www.ensilagem.com.br/wp-content/uploads/2013/0 4/G ROBFUTTERBEWERTUNG-II.pdf Acesso em: 22 dez 2015.

[4] Tomich, T. R., PEREIRA, L. G. R., GONÇALVES, L. C., TOMICH, R. G. P., and BORGES, I. 2003. Características Químicas para Avaliação do Processo Fermentativo de Silagens: uma Proposta para Qualificação da Fermentação. EmbrapaPantanal, Corumbá, MT. 20p.

[5] Genever, L. 2015. Making Grass Silage for Better Returns. AHDB Beef \& Lamb is a Division of the Agriculture and Horticulture Development Board (AHDB). Stoneleigh Park, Kenilworth, Warwickshire. UK. 20p.

[6] Adesogan, A. T., and NEWMAN, Y. C. 2014. Silage Harvesting, Storing, and Feeding. Agronomy Department, UF/IFAS Extension. Document SS-AGR-177.EUA, 7p.

[7] Kaiser, A. G., and Piltz, J. W. 2004. Feed Testing: Assessing Silage Quality—Chapter 12. Eds: KAISER, A. G., Piltz, J. W., BURNS, H. M., Griffiths, N. W. "Feeding Silage to Dairy Cows." In: Top Fodder Successful Silage. Second Edition. Australia. pp.312-33,468.

[8] Maccalman, H.,, Buckingham, S., and Powell, H. 2016. Why Analyse Silage? Fact Sheet. Behalf of the Welsh Government. November, 2012. 7p. Disponívelem: www.menterabusnes.co.uk/farming connect Acessoem: 05 jan 2016. 